\title{
Development and Quality Evaluation of Choco Quinoa Nutri Bar during Storage
}

\author{
Ananthan Padmashree, Neha Negi, Soorya Haridas, Thimma Govindaraj, \\ Kandanganth Raghavan Anila Kumar, Anil Dutt Semwal, Gopal Kumar Sharma* \\ Defence Food Research Laboratory, Siddartha Nagar, Mysuru, India \\ Email: *gk.sharma@dfrl.drdo.in, *gksh60@gmail.com
}

How to cite this paper: Padmashree, A., Negi, N., Haridas, S., Govindaraj, T., Kumar, K.R.A., Semwal, A.D. and Sharma, G.K. (2018) Development and Quality Evaluation of Choco Quinoa Nutri Bar during Storage. Food and Nutrition Sciences, 9, 899-914.

https://doi.org/10.4236/fns.2018.97067

Received: February 13, 2018

Accepted: July 27, 2018

Published: July 30, 2018

Copyright $\odot 2018$ by authors and Scientific Research Publishing Inc. This work is licensed under the Creative Commons Attribution International License (CC BY 4.0).

http://creativecommons.org/licenses/by/4.0/

\section{Open Access}

\begin{abstract}
Choco quinoa nutri bar was developed using quinoa as one of the ingredients to explore its nutritional benefits. Bars were packed in polypropylene (PP, 75 $\mu$ ) and metallised polyester $(12 \mu)$ low density-high density (MP, $100 \mu)$ (with/without vacuum) films, stored under ambient and $37^{\circ} \mathrm{C}$ temperature conditions for shelf life evaluation. Bar contained $14.43 \%$ protein, $14.93 \%$ fat with a calorific value of $426.75 \mathrm{k} \mathrm{cal} / 100 \mathrm{~g}$. Chemical changes were observed significantly $(\mathrm{p}<0.05)$ more in the samples stored at $37^{\circ} \mathrm{C}$ than the ones stored at ambient conditions $\left(15^{\circ} \mathrm{C}-34^{\circ} \mathrm{C}\right)$. Bars showed maximum stability at $0.33 \mathrm{a}_{\mathrm{w}}$ with less chemical changes. Oleic acid (36.06\%) was found to be the major fatty acids in the bar followed by palmitic (29.35\%), stearic (17.12\%) and linoleic (12.05\%) acids. Hardness of the bar enhanced significantly during storage, and was observed significantly $(\mathrm{p}<0.05)$ higher in the samples packed in MP films (with/without vacuum) as compared to bars packed in PP films thus restricting the shelf life of the bar to 6 months in MP films (with/without vacuum) and 9 months in PP films at both the temperature conditions.
\end{abstract}

\section{Keywords}

Choco Quinoa Nutri Bar, Quinoa, Packaging Material, Chemical Changes, Hardness, Shelf Life

\section{Introduction}

Quinoa (Chenopodium quinoa Wild) is referred to as a pseudo-cereal, produces seeds of pale yellow colour, but may vary from white through pink, orange or red to brown and black [1]. Quinoa is rich in its nutritive value, with remarkable protein content and its protein nutrient is comparable to that of milk protein [2] 
[3]. It also has an excellent amino acid composition and amino acids like lysine, methionine and cysteine, also presents in higher amounts than common cereals and legumes [1] and can act as a potential protein substitute in food [4] [5].

Quinoa's fat content goes up to 9.5\% [2], contains beneficial fatty acids, higher content of tocopherols and is also a rich source of $\mathrm{Ca}, \mathrm{Fe}, \mathrm{Zn}, \mathrm{Cu}$ and $\mathrm{Mn}$ [6]. Since quinoa is gluten free, ideal for persons suffering from celiac disease, can be used in different forms like flour, flakes, puffed grains etc. in the formulation of varieties of food preparations.

Nutrition/snack/energy bars, generally termed as food bars, are convenient foods; mainly consist of cereals and other high energy ingredients. These bars provide good sensory and nutritional characteristics due to the presence of carbohydrate, lipids, proteins and minerals in them. The changes in life style and dietary pattern, increasing awareness about healthy food habits with adequate nutritional requirements and increased physical activity has made energy bars a perfect choice as a quality source of energy [7].

In the present study, quinoa has been used as one of the ingredients due to its high nutritional value along with the other ingredients viz cocoa powder, cocoa butter, raisins, nuts etc. for the preparation of choco quinoa nutri bar and evaluated for its oxidative stability by packing them in polypropylene (PP), Metallised Polyester (MP, with and without vacuum), storing them at ambient $\left(15^{\circ} \mathrm{C}\right.$ $34^{\circ} \mathrm{C}$ ) and $37^{\circ} \mathrm{C}$ temperature conditions.

\section{Materials and Methods}

The ingredients used in the preparation of choco quinoa nutri bar consist of quinoa crispies obtained from M/s Quessentials Pvt Ltd, Ananthpur. Whey protein concentrate, procured from M/s Strategic Marketing and Research, Bengaluru. Cocoa powder (Cadbury brand), cocoa butter, raisins, oats (Baggery brand), liquid glucose and almond obtained from local market of Mysuru.

All the chemicals and solvents used in the present study were of analytical reagent grade.

\subsection{Preparation of a Bar}

The various ingredients used for the standardization of recipe for the preparation of choco quinoa nutri bar consists of quinoa crispies in the range of (15\% $20 \%)$, raisins $(5 \%-8 \%)$, almonds $(5 \%-8 \%)$, cocoa butter $(10 \%-15 \%)$, oat flakes (5\% - 8\%), liquid glucose (2\% - 5\%), sugar (25\% - 30\%) and cocoa powder (5\% - 8\%). The standaridized formulation of choco quinoa nutri bar comprised of quinoa crispies (17.2\%) dried in a hot air oven at $80^{\circ} \mathrm{C}$ for $4 \mathrm{hr}$, raisins $(6.9 \%)$, almonds $(6.9 \%)$ cut in to small pieces and dried in a hot air oven at $70^{\circ} \mathrm{C}$ till it reached 3\% - 4\% moisture and found crispy, melted cocoa butter $(13.8 \%)$, oat flakes (6.9\%) roasted up to $130^{\circ} \mathrm{C}$, liquid glucose (3.5\%), sugar (27.5\%) and cocoa powder (6.9\%). Each of the above ingredients required for making 90 bars/batch was weighed consisting of $2.5 \mathrm{~kg}$ of the mixed material in total. 
Binder solution was prepared by heating refined sugar and water (1:1) along with the liquid glucose to a temperature of $110^{\circ} \mathrm{C}$. Melted cocoa butter was added and mixed well. To the above hot binder syrup, mixture of dry ingredients was added and mixed. After mixing of the ingredients thoroughly with the binder syrup, the contents were transferred to a mould and compressed by applying a pressure of $492-562 \mathrm{~kg} / \mathrm{cm}^{2}$, cooled and packed in Polypropylene (PP) and Metallised Polyester (MP) pouches (also packed under vacuum in MP pouches), stored at ambient and $37^{\circ} \mathrm{C}$ temperature conditions for shelf life evaluation.

\subsection{Methods}

Moisture, fat, protein and total ash contents were estimated as per the standard methods of AOAC (1984) [8]. Peroxide value, free fatty acids as well as fatty acid profile were estimated by the method of AOCS (1990) [9]. Total sugar was estimated as per the method described by Khan et al. (2008) [10]. Analysis of amino acid composition was carried out as per the procedure of Henderson et al. (2000) [11]. TBA value was determined by the method of Tarledgis et al. (1960) [12]. Antioxidant activity by DPPH was measured according to the method of Braca et al. (2001) [13]. Microbiological analysis of bar was carried out as per the method of APHA (1992) [14].

\subsubsection{Measurement of Browning Index}

Browning intensity (OD) in choco quinoa nutri bar was carried out as per the method of Khan et al. [15] by shaking $5 \mathrm{~g}$ of powdered bar sample with 70:30 ethanol/water for $2 \mathrm{~h}$ and measuring optical density at $420 \mathrm{~nm}$.

\subsubsection{Effect of $\mathrm{a}_{\mathrm{w}}$ on Lipid Peroxidation}

The effect of water activity $\left(a_{w}\right)$ on lipid peroxidation was determined by keeping $120 \mathrm{~g}$ samples in desiccators for 40 days at ambient temperature $\left(15^{\circ} \mathrm{C}-34^{\circ} \mathrm{C}\right)$ containing phosphorous pentoxide to obtain 0.0 water activity $\left(\mathrm{a}_{\mathrm{w}}\right)$ and saturated solutions of magnesium chloride, sodium bromide, sodium nitrate and barium chloride to obtain water activities $\left(\mathrm{a}_{\mathrm{w}}\right)$ of $0.33,0.57,0.73$ and 0.90 respectively. Initially and periodically at an interval of 10 days, stored samples were analysed for moisture, peroxide value, free fatty acid value, thiobarbituric acid value and antioxidant activity.

\subsubsection{Texture Analysis}

The firmness of the sample as shear force was measured using a texture analyser (TA HD Plus, Stable Micro Systems, London, UK) equipped with $50 \mathrm{~kg}$ load cell and extended craft knife operated at a test speed of $5 \mathrm{~mm} / \mathrm{sec}$. Firmness was the maximum force recorded on the chart in $\mathrm{kg}$. The data obtained from texture profile analysis were used for determining the toughness and shear value.

\subsubsection{Sensory Evaluation}

The sensory characteristics of samples were evaluated in terms of colour, aroma, taste, texture and overall acceptability using a 9 point Hedonic scale, grading 9 
for excellent and 1 for highly disliked sample by a semi trained panel of judges consisting of 20 panelists. Samples were randomly drawn from each experimental block, coded and served to the panellists randomly and were asked to grade based on 9 point Hedonic scale [16].

\subsubsection{Statistical Analysis}

The data analysis was performed using statistical software (Statistica, Ver 7.1 Series 1205). Statistical significance between the parameters were assessed by 3 way ANOVA using Duncan's multiple range test by considering significance at $\mathrm{p}<$ 0.05 [17].

\section{Results and Discussion}

Analysis of proximate composition of choco quinoa nutri bar (Table 1) indicated the moisture content of $7.33 \%$, while crude fat and crude protein found almost similar showing the values of $14.91 \%$ and $14.43 \%$ respectively. Bar contained $1.48 \%$ total ash, $3.14 \%$ crude fibre and $61.85 \%$ carbohydrate with a calorific value of $426.75 \mathrm{k} \mathrm{cal} / 100 \mathrm{~g}$.

Quinoa has an excellent amino acid balance with higher lysine (5.1\% to $6.4 \%)$ and methionine $(0.4 \%$ to $1.0 \%)$ contents [18] [19] [20]. Hence, in order to explore the beneficial effects of this wonder pseudocereal, quinoa in the form of crispies has been incorporated in the preparation of a bar and the amino acid contents of the same has been demonstrated in the Figure 1. Choco quinoa nutri bar exhibited very good amounts of branched chain amino acids viz isoleucine $(688.80 \mathrm{mg} / 100 \mathrm{~g})$, leucine $(892.10 \mathrm{mg} / 100 \mathrm{~g})$ and valine $530.40 \mathrm{mg} / 100 \mathrm{~g})$ and amino acid lysine was also found to be present in fairly good amount (561.01 $\mathrm{mg} / 100 \mathrm{~g}$ ). Bar showed $388.90 \mathrm{mg} / 100 \mathrm{~g}$ of threonine and other essential amino acids were found between the range of $110-181 \mathrm{mg} / 100 \mathrm{~g}$. L-Aspartic acid was found in higher amounts $(596.26 \mathrm{mg} / 100 \mathrm{~g})$ among the non-essential amino acids identified in the bar followed by L-Alanine $(301.50 \mathrm{mg} / 100 \mathrm{~g})$ and L-Proline $(308.40 \mathrm{mg} / 100 \mathrm{~g})$. L-Cysteine was found in a very meagre amount i.e., 30.01 $\mathrm{mg} / 100 \mathrm{~g}$ in the bar.

Table 1. Proximate composition of choco-quinoa nutri Bar.

\begin{tabular}{cc}
\hline Attributes & $(\%)$ \\
\hline Moisture & $7.33 \pm 0.08$ \\
Crude Fat & $14.91 \pm 0.12$ \\
Crude Protein & $14.43 \pm 0.19$ \\
Total Ash & $1.48 \pm 0.04$ \\
Crude Fiber & $3.14 \pm 0.05$ \\
Total Carbohydrate & $61.85 \pm 0.12$ \\
Total sugars & $37.06 \pm 0.28$ \\
Energy (kcal/100g) & $426.75 \pm 0.49$
\end{tabular}

Values are mean $\pm S D,(n=3)$. 

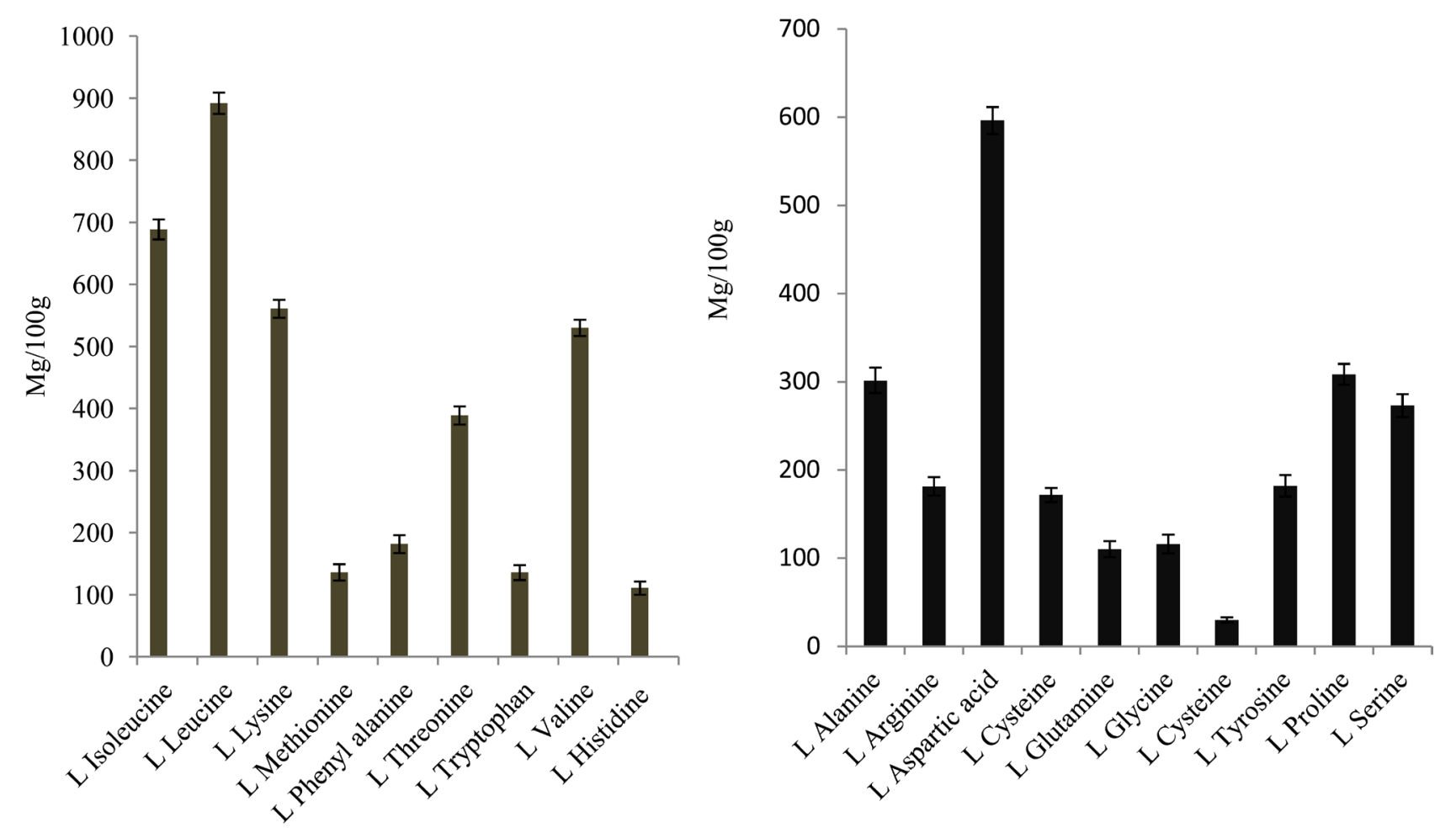

Figure 1. Essential and non essential amino acid contents (\%) in choco-quinoa nutri bar.

Lipid oxidation is one of the important processes that occurs in most of the food systems and a major cause of food deterioration during processing and storage [21]. In the present study, the extent of lipid oxidation of choco quinoa nutri bar has been monitored by studying the changes that took place in peroxide value (PV), free fatty acids (FFA), thiobarbituric acid (TBA) and browning index (BI) during storage at ambient $\left(15^{\circ} \mathrm{C}-34^{\circ} \mathrm{C}\right)$ and $37^{\circ} \mathrm{C}$ temperature conditions in different packaging materials (Table 2). During storage, moisture showed a significant $(\mathrm{p}<0.05)$ increase irrespective of storage period and temperature of storage. PP being high in water vapour transmission rate contributed significantly to the increase in moisture content as compared to the bars stored in MP films. During 9 months of storage, bars packed in PP films exhibited an increase in moisture content from $7.33 \%$ to $8.85 \%$ and $8.21 \%$ at ambient $\left(15^{\circ} \mathrm{C}\right.$ $34^{\circ} \mathrm{C}$ ) and $37^{\circ} \mathrm{C}$ temperature conditions respectively. Between vacuum and non vacuum packed samples in MP films, moisture content did not vary significantly $(\mathrm{p}<0.05)$ at both temperature conditions during storage. The degree of oxidation of a bar as measured by changes in PV revealed that, the bar that initially showed a PV of 5.31 attributed an increase to a maximum value of 13.18 meq $\mathrm{O}_{2} / \mathrm{kg}$ fat during 9 months of storage irrespective of the storage period, packaging material and temperature of storage. The increase in moisture content and possible presence of lipase enzyme in bars contributed to the significant ( $\mathrm{p}<$ 0.05 ) increase in FFA content during storage and it increased from $1.32 \%$ oleic acid to $2.78 \%, 2.63 \%, 2.49 \%$ oleic acid at ambient conditions $\left(15^{\circ} \mathrm{C}-34^{\circ} \mathrm{C}\right)$ and $3.45 \%, 3.21 \%$ and $3.10 \%$ oleic acid at $37^{\circ} \mathrm{C}$. TBA value also showed a similar 
Table 2. Changes in Moisture content (\%), Peroxide value (PV, meq $\mathrm{O}_{2} / \mathrm{kg}$ oil), Free fatty acid content (FFA,\% Oleic acid), Thiobarbituric acid value (TBA, mg malonaldehyde/kg sample) and Browning index (OD) of choco-quinoa nutri bar during storage at ambient $\left(15^{\circ} \mathrm{C}-34^{\circ} \mathrm{C}\right)$ conditions and $37^{\circ} \mathrm{C}$.

\begin{tabular}{|c|c|c|c|c|c|c|c|c|}
\hline \multirow{2}{*}{ Parameters } & \multirow{2}{*}{$\begin{array}{l}\text { Packaging } \\
\text { material }\end{array}$} & \multirow{2}{*}{$\mathrm{OM}$} & $3 \mathrm{M}$ & $6 \mathrm{M}$ & $9 \mathrm{M}$ & $3 \mathrm{M}$ & $6 \mathrm{M}$ & $9 \mathrm{M}$ \\
\hline & & & \multicolumn{3}{|c|}{$\mathrm{RT}$} & \multicolumn{3}{|c|}{$37^{\circ} \mathrm{C}$} \\
\hline \multirow{3}{*}{ Moisture content } & $\mathrm{PP}$ & & $8.01^{\mathrm{e}}$ & $8.47^{\mathrm{g}}$ & $8.85^{\mathrm{h}}$ & $7.62^{\mathrm{cd}}$ & $7.93^{e}$ & $8.21^{\mathrm{f}}$ \\
\hline & MP & $7.33^{\mathrm{a}}$ & $7.52^{\mathrm{bc}}$ & $7.69^{\mathrm{cd}}$ & $7.74^{\mathrm{d}}$ & $7.45^{\mathrm{ab}}$ & $7.63^{\mathrm{cd}}$ & $7.70^{\mathrm{d}}$ \\
\hline & $\mathrm{MP}(\mathrm{Vac})$ & & $7.42^{\mathrm{ab}}$ & $7.51^{\mathrm{bc}}$ & $7.55^{\mathrm{bc}}$ & $7.29^{\mathrm{a}}$ & $7.45^{\mathrm{ab}}$ & $7.51^{\mathrm{bc}}$ \\
\hline \multirow{3}{*}{ Peroxide value } & $\mathrm{PP}$ & & $7.11^{\mathrm{c}}$ & $9.36^{\mathrm{g}}$ & $11.69^{\mathrm{i}}$ & $7.89^{\mathrm{d}}$ & $10.98^{\mathrm{h}}$ & $13.18^{\mathrm{k}}$ \\
\hline & MP & $5.31^{\mathrm{a}}$ & $6.85^{\mathrm{c}}$ & $8.19^{\mathrm{d}}$ & $10.42^{\mathrm{g}}$ & $7.10^{\mathrm{c}}$ & $10.22^{\mathrm{g}}$ & $12.45^{\mathrm{j}}$ \\
\hline & $\mathrm{MP}(\mathrm{Vac})$ & & $6.20^{\mathrm{b}}$ & $7.89^{\mathrm{d}}$ & $8.76^{\mathrm{e}}$ & $6.86^{\mathrm{c}}$ & $9.34^{\mathrm{f}}$ & $11.68^{\mathrm{i}}$ \\
\hline \multirow{3}{*}{ Free fatty acid } & PP & & $1.89^{\mathrm{d}}$ & $2.32^{\mathrm{fg}}$ & $2.78^{\mathrm{i}}$ & $2.16^{\mathrm{ef}}$ & $2.76^{\mathrm{i}}$ & $3.45^{\mathrm{k}}$ \\
\hline & MP & $1.32^{\mathrm{a}}$ & $1.70^{\mathrm{bc}}$ & $2.12^{\mathrm{e}}$ & $2.63^{\mathrm{hi}}$ & $1.97^{\mathrm{de}}$ & $2.55^{\mathrm{h}}$ & $3.21^{j}$ \\
\hline & $\mathrm{MP}(\mathrm{Vac})$ & & $1.62^{\mathrm{b}}$ & $1.90^{\mathrm{d}}$ & $2.49^{\text {gh }}$ & $1.82^{\mathrm{cd}}$ & $2.30^{\mathrm{fg}}$ & $3.10^{\mathrm{j}}$ \\
\hline \multirow{3}{*}{$\begin{array}{c}\text { Thiobarbituric } \\
\text { acid }\end{array}$} & PP & & $0.14^{\mathrm{cd}}$ & $0.16^{\mathrm{ef}}$ & $0.19^{\mathrm{h}}$ & $0.15^{\mathrm{de}}$ & $0.18^{\text {gh }}$ & $0.21^{\mathrm{i}}$ \\
\hline & MP & $0.11^{\mathrm{a}}$ & $0.13^{\mathrm{bc}}$ & $0.15^{\mathrm{de}}$ & $0.17^{\mathrm{fg}}$ & $0.14^{\mathrm{cd}}$ & $0.17^{\mathrm{fg}}$ & $0.19^{\mathrm{h}}$ \\
\hline & $\mathrm{MP}(\mathrm{Vac})$ & & $0.12^{\mathrm{ab}}$ & $0.14^{\mathrm{cd}}$ & $0.17^{\mathrm{fg}}$ & $0.13^{\mathrm{bc}}$ & $0.15^{\mathrm{de}}$ & $0.18^{\text {gh }}$ \\
\hline \multirow{3}{*}{ Browning Index } & PP & & $0.282^{\mathrm{e}}$ & $0.352^{\mathrm{h}}$ & $0.431^{1}$ & $0.295^{\mathrm{f}}$ & $0.367^{\mathrm{i}}$ & $0.455^{\mathrm{m}}$ \\
\hline & MP & $0.231^{\mathrm{a}}$ & $0.261^{c}$ & $0.333^{\mathrm{g}}$ & $0.401^{j}$ & $0.284^{\mathrm{e}}$ & $0.352^{\mathrm{h}}$ & $0.430^{1}$ \\
\hline & $\mathrm{MP}(\mathrm{Vac})$ & & $0.250^{\mathrm{b}}$ & $0.290^{\text {ef }}$ & $0.371^{\mathrm{i}}$ & $0.270^{\mathrm{d}}$ & $0.329^{\mathrm{g}}$ & $0.418^{\mathrm{k}}$ \\
\hline
\end{tabular}

Values with different superscripts differ significantly $(\mathrm{p}<0.05)$; Values are mean $\pm \mathrm{SD},(\mathrm{n}=3)$.

pattern of increase in both PP and MP films under the same conditions of storage of choco quinoa nutri bar. It is evident from the study that, the bar stored in PP films underwent slightly higher degree of deterioration as compared to the ones stored in MP films, can be due to their higher oxygen and water permeability rates than that of MP films. Khan et al. (2008) [10], also reported higher rate of chemical deterioration in ground nut burfi samples packed in PP films than MP films. The process of food browning which greatly affects the nutritional quality of stored foods has also undergone a significant $(\mathrm{P}<0.05)$ increase during storage of choco quinoa nutri bar. Fresh sample showed a browning index of 0.231 , enhanced significantly $(\mathrm{P}<0.05)$ to $0.431 \& 0.455$ in PP films, $0.401 \&$ 0.430 in MP films and $0.371 \& 0.418$ in samples stored under vacuum in MP films at ambient $\left(15^{\circ} \mathrm{C}-34^{\circ} \mathrm{C}\right)$ and $37^{\circ} \mathrm{C}$ temperature conditions respectively.

The lipid oxidation affected the antioxidant activity of the bar during storage at both the temperature conditions and the packaging materials used for the study (Figure 2). Initially bar has exhibited $58.74 \%$ inhibition of oxidation as measured by its antioxidant activity. With increase in the oxidation of the bar, the antioxidant activity was found to decrease significantly $(\mathrm{p}<0.05)$ in the bars stored at both ambient $\left(15^{\circ} \mathrm{C}-34^{\circ} \mathrm{C}\right)$ conditions and $37^{\circ} \mathrm{C}$ packed in all the 


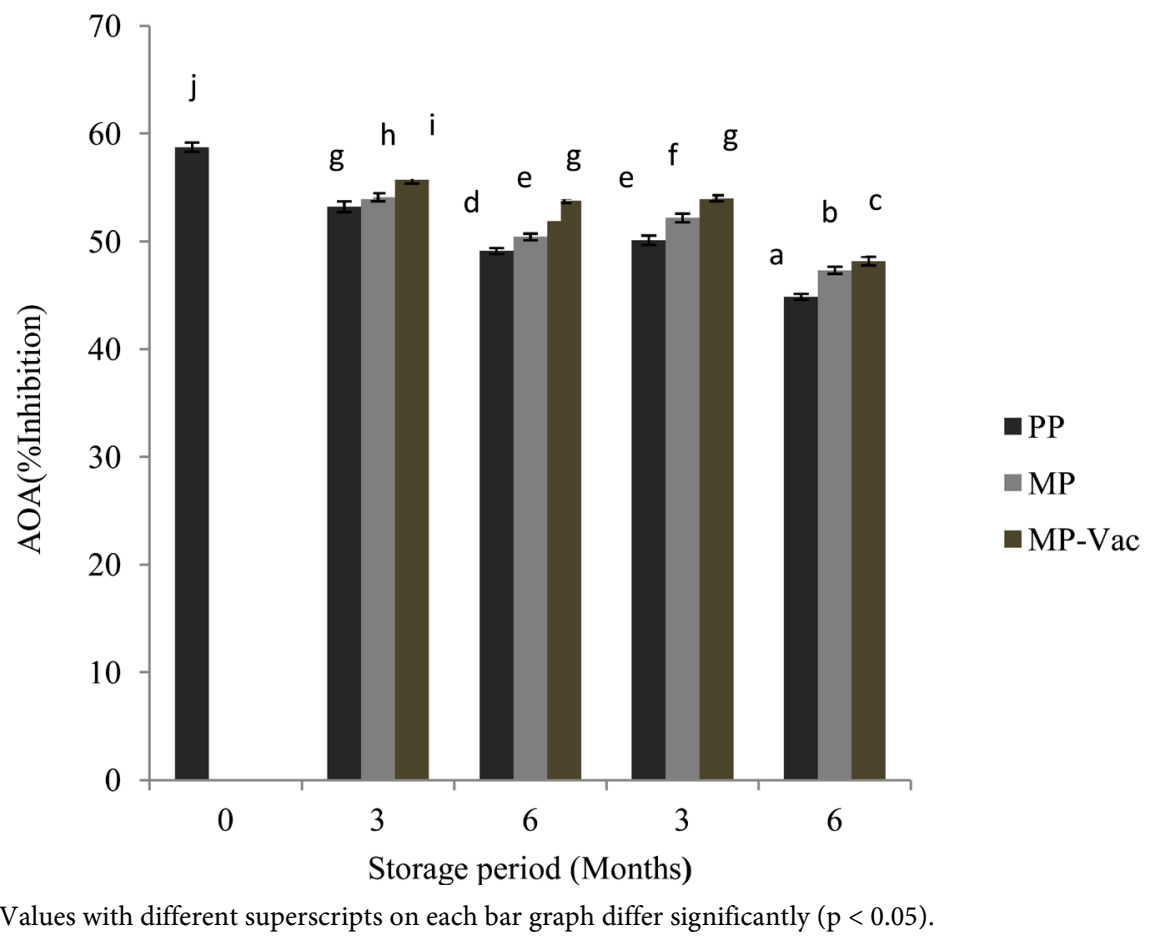

Figure 2. Changes in antioxidant activity of choco-quinoa nutri bar during storage at ambient conditions $\left(15^{\circ} \mathrm{C}-34^{\circ} \mathrm{C}\right)$ and $37^{\circ} \mathrm{C}$.

packaging materials during 9 months of storage. As expected, antioxidant activity decreased more in the samples packed in PP films than the samples stored in MP films (with and without vacuum), and found to correlate well with the oxidative changes that took place in different packaging material in the bar during storage at both the temperature conditions. Antioxidant activity decreased from $58.74 \%$ to $49.10 \%$ and $44.86 \%$ in PP packed samples at ambient condition $\left(15^{\circ} \mathrm{C}\right.$ $-34^{\circ} \mathrm{C}$ ) and $37^{\circ} \mathrm{C}$ respectively, while in samples packed in MP films decrease was found to be comparatively less and it decreased from 58.74 to $50.43 \& 47.32$ packed in MP films alone and $53.77 \& 48.17$ in samples stored under vacuum in MP films at ambient and $37^{\circ} \mathrm{C}$ temperature conditions respectively during 9 months of storage.

The fatty acid composition of choco quinoa nutri bar packed in PP and MP films (with/without vacuum), stored at ambient $\left(15^{\circ} \mathrm{C}-34^{\circ} \mathrm{C}\right)$ and $37^{\circ} \mathrm{C}$ temperature conditions are represented in the Table 3 . The major fatty acid identified was oleic acid (36.06\%) followed by palmitic (29.35\%) and stearic acids (17.12\%). Linoleic acid was also present in higher amounts (12.05\%), while linolenic acid in negligible amounts $(0.34 \%)$. During storage of the bar up to 9 months, there was a significant $(\mathrm{P}<0.05)$ decrease in unsaturated fatty acids representing oleic and linolenic acids with the concomitant increase in saturated fatty acids. As expected, samples stored under $37^{\circ} \mathrm{C}$ encountered higher degree of degradation of fatty acids than the samples stored under ambient conditions $\left(15^{\circ} \mathrm{C}-34^{\circ} \mathrm{C}\right)$ and also degradation was observed more in samples packed in PP films than MP packed samples. During storage of the bar in PP, MP and MP (vacuum) films, 
Table 3. Changes in fatty acid profile of choco-quinoa nutri bar during storage at ambient $\left(15^{\circ} \mathrm{C}-34^{\circ} \mathrm{C}\right)$ conditions and $37^{\circ} \mathrm{C}$

\begin{tabular}{|c|c|c|c|c|c|c|}
\hline \multirow{2}{*}{ Parameters } & \multirow{2}{*}{$\begin{array}{c}\text { Packaging } \\
\text { material }\end{array}$} & \multirow{2}{*}{$\mathrm{OM}$} & $6 \mathrm{M}$ & $9 \mathrm{M}$ & $6 \mathrm{M}$ & $9 \mathrm{M}$ \\
\hline & & & \multicolumn{2}{|c|}{$\mathrm{RT}$} & \multicolumn{2}{|c|}{$37^{\circ} \mathrm{C}$} \\
\hline \multirow{3}{*}{ Butyric } & $\mathrm{PP}$ & & $0.29^{\mathrm{a}}$ & $0.44^{\mathrm{b}}$ & $0.32^{\mathrm{ab}}$ & $0.50^{\mathrm{g}}$ \\
\hline & MP & $0.31^{\mathrm{a}}$ & $0.30^{\mathrm{ab}}$ & $0.35^{\mathrm{cd}}$ & $0.33^{\mathrm{bc}}$ & $0.38^{e}$ \\
\hline & $\mathrm{MP}(\mathrm{Vac})$ & & $0.29^{\mathrm{a}}$ & $0.32^{\mathrm{a}}$ & $0.31^{\mathrm{ab}}$ & $0.36^{\mathrm{de}}$ \\
\hline \multirow{3}{*}{ Caproic } & $\mathrm{PP}$ & & $0.38^{\mathrm{ab}}$ & $0.52^{\mathrm{f}}$ & $0.41^{\mathrm{c}}$ & $0.57^{\mathrm{g}}$ \\
\hline & MP & $0.36^{\mathrm{a}}$ & $0.36^{\mathrm{a}}$ & $0.42^{\mathrm{cd}}$ & $0.38^{\mathrm{ab}}$ & $0.49^{e}$ \\
\hline & $\mathrm{MP}(\mathrm{Vac})$ & & $0.38^{\mathrm{ab}}$ & $0.40^{\mathrm{bc}}$ & $0.42^{\mathrm{cd}}$ & $0.44^{\mathrm{d}}$ \\
\hline \multirow{3}{*}{ Caprylic } & $\mathrm{PP}$ & & $0.45^{\mathrm{c}}$ & $0.54^{\mathrm{e}}$ & $0.48^{\mathrm{d}}$ & $0.58^{\mathrm{f}}$ \\
\hline & MP & $0.42^{\mathrm{ab}}$ & $0.42^{\mathrm{ab}}$ & $0.45^{\mathrm{c}}$ & $0.45^{\mathrm{c}}$ & $0.48^{\mathrm{d}}$ \\
\hline & $\mathrm{MP}(\mathrm{Vac})$ & & $0.40^{\mathrm{a}}$ & $0.45^{\mathrm{c}}$ & $0.44^{\mathrm{bc}}$ & $0.48^{\mathrm{d}}$ \\
\hline \multirow{3}{*}{ Capric } & PP & & $0.58^{\mathrm{de}}$ & $0.64^{\mathrm{gh}}$ & $0.65^{\mathrm{h}}$ & $0.70^{\mathrm{i}}$ \\
\hline & MP & $0.50^{\mathrm{a}}$ & $0.55^{\mathrm{bc}}$ & $0.60^{\text {ef }}$ & $0.62^{\mathrm{fg}}$ & $0.64^{\mathrm{gh}}$ \\
\hline & $\mathrm{MP}(\mathrm{Vac})$ & & $0.52^{\mathrm{ab}}$ & $0.57^{\mathrm{cd}}$ & $0.54^{\mathrm{b}}$ & $0.63^{\mathrm{gh}}$ \\
\hline \multirow{3}{*}{ Lauric } & PP & & $1.22^{\mathrm{abc}}$ & $1.38^{\mathrm{bc}}$ & $1.30^{\mathrm{abc}}$ & $1.45^{\mathrm{c}}$ \\
\hline & MP & $1.08^{\mathrm{a}}$ & $1.19^{\mathrm{ab}}$ & $1.25^{\mathrm{abc}}$ & $1.25^{\mathrm{abc}}$ & $1.28^{\mathrm{abc}}$ \\
\hline & $\mathrm{MP}(\mathrm{Vac})$ & & $1.14^{\mathrm{ab}}$ & $1.20^{\mathrm{abc}}$ & $1.19^{\mathrm{ab}}$ & $1.25^{\mathrm{abc}}$ \\
\hline \multirow{3}{*}{ Myristic } & $\mathrm{PP}$ & & $1.47^{\mathrm{a}}$ & $1.59^{\mathrm{a}}$ & $1.54^{\mathrm{a}}$ & $1.63^{\mathrm{a}}$ \\
\hline & MP & $1.34^{\mathrm{a}}$ & $1.42^{\mathrm{a}}$ & $1.52^{\mathrm{a}}$ & $1.48^{\mathrm{a}}$ & $1.58^{\mathrm{a}}$ \\
\hline & $\mathrm{MP}(\mathrm{Vac})$ & & $1.39^{\mathrm{a}}$ & $1.48^{\mathrm{a}}$ & $1.45^{\mathrm{a}}$ & $1.53^{\mathrm{a}}$ \\
\hline \multirow{3}{*}{ Palmitic } & $\mathrm{PP}$ & & $29.88^{\mathrm{b}}$ & $30.55^{\mathrm{d}}$ & $29.94^{\mathrm{b}}$ & $30.42^{\mathrm{d}}$ \\
\hline & MP & $29.35^{\mathrm{a}}$ & $29.97^{b c}$ & $30.31^{\mathrm{cd}}$ & $29.83^{\mathrm{b}}$ & $30.41^{\mathrm{d}}$ \\
\hline & $\mathrm{MP}(\mathrm{Vac})$ & & $29.48^{\mathrm{a}}$ & $29.78^{\mathrm{ab}}$ & $29.57^{\mathrm{a}}$ & $29.94^{\mathrm{b}}$ \\
\hline \multirow{3}{*}{ Stearic } & $\mathrm{PP}$ & & $17.30^{\mathrm{a}}$ & $17.88^{\mathrm{de}}$ & $17.49^{\mathrm{b}}$ & $18.17^{\mathrm{e}}$ \\
\hline & MP & $17.12^{\mathrm{a}}$ & $17.23^{\mathrm{ab}}$ & $17.50^{\mathrm{bcd}}$ & $17.34^{\mathrm{abc}}$ & $17.64^{\mathrm{cd}}$ \\
\hline & $\mathrm{MP}(\mathrm{Vac})$ & & $17.19^{\mathrm{a}}$ & $17.32^{\mathrm{abc}}$ & $17.23^{\mathrm{ab}}$ & $17.55^{\mathrm{bcd}}$ \\
\hline \multirow{3}{*}{ Oleic } & PP & & $35.72^{\text {cde }}$ & $35.10^{\mathrm{ab}}$ & $35.60^{\mathrm{cd}}$ & $34.90^{\mathrm{a}}$ \\
\hline & MP & $36.06^{e}$ & $35.82^{\mathrm{de}}$ & $35.40^{\mathrm{bc}}$ & $35.74^{\text {cde }}$ & $35.28^{\mathrm{ab}}$ \\
\hline & $\mathrm{MP}(\mathrm{Vac})$ & & $35.90^{\mathrm{de}}$ & $35.68^{\mathrm{cd}}$ & $35.83^{\mathrm{de}}$ & $35.61^{\text {cde }}$ \\
\hline \multirow{3}{*}{ Linoleic } & PP & & $11.75^{\mathrm{cd}}$ & $11.32^{\mathrm{ab}}$ & $11.40^{\mathrm{ab}}$ & $11.10^{\mathrm{a}}$ \\
\hline & MP & $12.05^{\mathrm{e}}$ & $11.82^{\text {cde }}$ & $11.58^{\mathrm{bc}}$ & $11.71^{\mathrm{cd}}$ & $11.47^{\mathrm{abc}}$ \\
\hline & $\mathrm{MP}(\mathrm{Vac})$ & & $11.90^{\mathrm{de}}$ & $11.74^{\mathrm{cd}}$ & $11.83^{\text {cde }}$ & $11.55^{\mathrm{abcd}}$ \\
\hline \multirow{3}{*}{ Linolenic } & $\mathrm{PP}$ & & $0.28^{\mathrm{de}}$ & $0.20^{\mathrm{b}}$ & $0.25^{\mathrm{c}}$ & $0.12^{\mathrm{a}}$ \\
\hline & MP & $0.34^{\mathrm{g}}$ & $0.30^{\mathrm{ef}}$ & $0.25^{\mathrm{c}}$ & $0.28^{\mathrm{de}}$ & $0.20^{\mathrm{b}}$ \\
\hline & $\mathrm{MP}(\mathrm{Vac})$ & & $0.30^{\mathrm{ef}}$ & $0.25^{\mathrm{c}}$ & $0.31^{\mathrm{f}}$ & $0.21^{\mathrm{b}}$ \\
\hline
\end{tabular}

Values with different superscripts differ significantly $(\mathrm{p}<0.05)$; Values are mean $\pm S D,(n=3)$. 
linoleic acid was found to decrease significantly $(\mathrm{P}<0.05)$ from $12.05 \%$ to $11.32 \% \& 11.10 \%, 11.58 \% \& 11.47 \%$ and $11.74 \% \& 11.55 \%$ in the samples stored under ambient and $37^{\circ} \mathrm{C}$ temperature conditions respectively. Oleic acid underwent higher degree of degradation from $36.06 \%$ to $35.10 \%$ \& $34.90 \%$ packed in PP films, 35.40\% \& $35.28 \%$ packed in MP films and 35.68\% \& $35.61 \%$ packed in MP films under vacuum at ambient $\left(15^{\circ} \mathrm{C}-34^{\circ} \mathrm{C}\right)$ and $37^{\circ} \mathrm{C}$ temperature conditions respectively. The major saturated fatty acid, palmitic increased significantly $(\mathrm{p}<0.05)$ by $1.2,0.96$ and 0.43 units at ambient conditions $\left(15^{\circ} \mathrm{C}-34^{\circ} \mathrm{C}\right)$ and $1.07,1.06$ and 0.59 units at $37^{\circ} \mathrm{C}$ packed in PP, MP and MP (vacuum) films respectively. The next major saturated fatty acid myristic also showed a significant $(\mathrm{P}<0.05)$ increase during storage by maximum 0.25 units under ambient conditions $\left(15^{\circ} \mathrm{C}-34^{\circ} \mathrm{C}\right)$ and 0.29 units under $37^{\circ} \mathrm{C}$ irrespective of the packaging material used. The other lower chain fatty acids like butyric, caproic, and capric acids also showed a slight and significant $(\mathrm{p}<0.05)$ increase during storage.

Texture is a critical sensory attribute which determines the quality of a food and is related to the deformation, disintegration and flow of a food when a force is applied on them [22]. In the study, texture of choco quinoa nutri bar was described using toughness and work of shear by measuring the cut force (Table 4). It is evident from the data that, toughness, a total positive area under the curve or the work required to cut the sample of a bar varied significantly $(\mathrm{p}<0.05)$ during 9 months of storage and it increased significantly $(\mathrm{P}<0.05)$ from 4.46 to $7.35 \& 7.89,8.56 \& 8.93,9.12 \& 9.56 \mathrm{~kg}$ in the samples stored under ambient and $37^{\circ} \mathrm{C}$ temperature conditions in PP, MP and MP (Vacuum) films respectively. The highest value for toughness was shown by bars stored under vacuum in MP films at $37^{\circ} \mathrm{C}(9.56 \mathrm{~kg})$ and lowest in PP films at ambient conditions $(7.35 \mathrm{~kg})$ at the end of the storage period.

As the toughness of the bar increased, the work of shear which measures samples shearing resistance force when cut by a knife decreased significantly $(\mathrm{P}<$ 0.05). During storage, as the bar started losing its pliability with the increased hardness, the total force under the larger area which measures work of shear decreased significantly $(\mathrm{P}<0.05)$ from 17.31 to $15.6414 .87,14.28 \mathrm{~kg} \cdot \mathrm{mm}$ at ambient

Table 4. Changes in cutting strength of choco-quinoa nutri bar during storage at ambient conditions $\left(15^{\circ} \mathrm{C}-34^{\circ} \mathrm{C}\right)$ and $37^{\circ} \mathrm{C}$.

\begin{tabular}{|c|c|c|c|c|c|c|c|c|}
\hline \multirow{2}{*}{ Parameters } & \multirow{2}{*}{$\begin{array}{c}\text { Packaging } \\
\text { material }\end{array}$} & \multirow{2}{*}{$0 \mathrm{M}$} & $3 \mathrm{M}$ & $6 \mathrm{M}$ & $9 \mathrm{M}$ & $3 \mathrm{M}$ & $6 \mathrm{M}$ & $9 \mathrm{M}$ \\
\hline & & & \multicolumn{3}{|c|}{ RT } & \multicolumn{3}{|c|}{$37^{\circ} \mathrm{C}$} \\
\hline \multirow{3}{*}{$\begin{array}{c}\text { Toughness } \\
(\mathrm{kg})\end{array}$} & $\mathrm{PP}$ & & $4.69^{\mathrm{a}}$ & $6.15^{c}$ & $7.35^{\mathrm{e}}$ & $4.98^{\mathrm{a}}$ & $6.38^{c}$ & $7.89^{f}$ \\
\hline & $\mathrm{MP}$ & $4.46^{\mathrm{a}}$ & $4.71^{\mathrm{a}}$ & $6.73^{\mathrm{d}}$ & $8.56^{\mathrm{g}}$ & $5.03^{\mathrm{a}}$ & $6.92^{\mathrm{de}}$ & $8.93^{\mathrm{g}}$ \\
\hline & $\mathrm{MP}(\mathrm{Vac})$ & & $4.80^{\mathrm{a}}$ & $6.82^{\mathrm{d}}$ & $9.12^{\mathrm{h}}$ & $5.15^{\mathrm{b}}$ & $7.11^{\mathrm{de}}$ & $9.56^{\mathrm{h}}$ \\
\hline \multirow{3}{*}{$\begin{array}{l}\text { Work of } \\
\text { shear } \\
(\mathrm{kg} \mathrm{mm})\end{array}$} & PP & & $17.00^{\mathrm{h}}$ & $16.41^{\mathrm{fg}}$ & $15.64^{\mathrm{cd}}$ & $16.25^{\mathrm{f}}$ & $16.27^{\mathrm{f}}$ & $15.45^{\mathrm{c}}$ \\
\hline & MP & $17.31^{\mathrm{i}}$ & $16.88^{\mathrm{gh}}$ & $16.10^{\mathrm{ef}}$ & $14.87^{\mathrm{b}}$ & $16.10^{\mathrm{ef}}$ & $16.01^{\mathrm{def}}$ & $14.40^{\mathrm{ab}}$ \\
\hline & $\mathrm{MP}(\mathrm{Vac})$ & & $16.70^{\mathrm{gh}}$ & $15.74^{\mathrm{cde}}$ & $14.28^{\mathrm{a}}$ & $16.50^{\mathrm{fg}}$ & $15.58^{\mathrm{c}}$ & $14.14^{\mathrm{a}}$ \\
\hline
\end{tabular}

Values with different superscripts differ significantly $(\mathrm{p}<0.05)$, Values are mean $\pm S D,(n=3)$. 
conditions and $15.45,14.40,14.14 \mathrm{~kg} \cdot \mathrm{mm}$ at $37^{\circ} \mathrm{C}$, packed in PP, MP and MP (vacuum) films respectively. At a particular interval of time, w.r.t the same packaging material, and at both the temperature conditions, toughness and work of shear did not vary significantly $(\mathrm{p}<0.05)$, revealing same observations for the texture of the bar from sensory panellists.

Sensory acceptance of choco quinoa nutri bar was assessed by studying the changes in terms of colour, aroma, taste, texture and over all acceptability (OAA) scores during storage at ambient and $37^{\circ} \mathrm{C}$ temperature conditions in different packaging materials (Table 5). Significant $(\mathrm{P}<0.05)$ differences were observed in the above sensory parameters during storage of a bar. Highest values for colour, aroma and taste were found to be $8.07,8.10$ and 8.20 respectively at zero day of storage and least value was observed in samples stored in PP films during 9 months of storage at $37^{\circ} \mathrm{C}$ on a 9 point Hedonic scale. However, between the packaging material and temperature of storage, colour, aroma and taste parameters in bar did not vary significantly $(p>0.05)$ at each interval of time. Though these sensory parameters has not affected the acceptance of the bar, the significant $(\mathrm{p}<0.05)$ textural changes observed after 3 months of storage resulted in hardness of a bar, which inturn affected the acceptability and hence shelf-life. Texture of the bar did not vary significantly $(p>0.05)$ between the samples packed in MP films (with and without vacuum) at each interval of

Table 5. Changes in sensory attributes of choco-quinoa nutri bar during storage at ambient conditions $\left(15^{\circ} \mathrm{C}-34^{\circ} \mathrm{C}\right)$ and $37^{\circ} \mathrm{C}$.

\begin{tabular}{|c|c|c|c|c|c|c|c|c|}
\hline \multirow{2}{*}{ Parameters } & \multirow{2}{*}{$\begin{array}{c}\text { Packaging } \\
\text { materials }\end{array}$} & \multirow{2}{*}{$\mathrm{OM}$} & $3 \mathrm{M}$ & $6 \mathrm{M}$ & $9 \mathrm{M}$ & $3 \mathrm{M}$ & $6 \mathrm{M}$ & $9 \mathrm{M}$ \\
\hline & & & \multicolumn{3}{|c|}{$\mathrm{RT}$} & \multicolumn{3}{|c|}{$37^{\circ} \mathrm{C}$} \\
\hline \multirow{3}{*}{ Colour } & $\mathrm{PP}$ & & $7.82^{\mathrm{de}}$ & $7.52^{\mathrm{bc}}$ & $7.25^{\mathrm{ab}}$ & $7.73^{\mathrm{de}}$ & $7.45^{\mathrm{bc}}$ & $7.17^{\mathrm{a}}$ \\
\hline & MP & $8.07^{\mathrm{f}}$ & $7.93^{\mathrm{ef}}$ & $7.63^{\mathrm{cd}}$ & $7.38^{\mathrm{abc}}$ & $7.80^{\mathrm{def}}$ & $7.52^{\mathrm{bc}}$ & $7.32^{\mathrm{ab}}$ \\
\hline & $\mathrm{MP}(\mathrm{Vac})$ & & $7.90^{\mathrm{ef}}$ & $7.71^{\mathrm{de}}$ & $7.45^{\mathrm{bc}}$ & $7.88^{\mathrm{def}}$ & $7.62^{\mathrm{cd}}$ & $7.40^{\mathrm{bc}}$ \\
\hline \multirow{3}{*}{ Aroma } & $\mathrm{PP}$ & & $7.85^{\mathrm{efg}}$ & $7.62^{\text {cde }}$ & $7.29^{\mathrm{ab}}$ & $7.71^{\text {cdef }}$ & $7.50^{\mathrm{bcd}}$ & $7.12^{\mathrm{a}}$ \\
\hline & MP & $8.10^{\mathrm{g}}$ & $7.90^{\mathrm{fg}}$ & $7.71^{\text {cdef }}$ & $7.45^{\mathrm{bc}}$ & $7.78^{\mathrm{def}}$ & $7.70^{\text {cdef }}$ & $7.23^{\mathrm{ab}}$ \\
\hline & MP (Vac) & & $7.90^{\mathrm{fg}}$ & $7.77^{\mathrm{def}}$ & $7.51^{\mathrm{bc}}$ & $7.83^{\mathrm{efg}}$ & $7.75^{\text {cdef }}$ & $7.39^{\mathrm{ab}}$ \\
\hline \multirow{3}{*}{ Taste } & $\mathrm{PP}$ & & $7.80^{\text {ef }}$ & $7.55^{\mathrm{bcd}}$ & $7.29^{\mathrm{ab}}$ & $7.68^{\text {cdef }}$ & $7.42^{\mathrm{abc}}$ & $7.20^{\mathrm{a}}$ \\
\hline & MP & $8.20^{\mathrm{g}}$ & $7.89^{\mathrm{ef}}$ & $7.65^{\text {cdef }}$ & $7.40^{\mathrm{abc}}$ & $7.73^{\mathrm{def}}$ & $7.49^{\mathrm{abcd}}$ & $7.32^{\mathrm{ab}}$ \\
\hline & MP (Vac) & & $7.93^{\mathrm{fg}}$ & $7.74^{\text {def }}$ & $7.51^{\mathrm{abcd}}$ & $7.81^{\mathrm{ef}}$ & $7.60^{\text {cde }}$ & $7.44^{\mathrm{abc}}$ \\
\hline \multirow{3}{*}{ Texture } & PP & & $7.74^{j}$ & $7.40^{\mathrm{hi}}$ & $7.10^{\mathrm{fgh}}$ & $7.62^{\mathrm{ij}}$ & $7.27^{\text {gh }}$ & $6.80^{\mathrm{ef}}$ \\
\hline & MP & $8.09^{\mathrm{k}}$ & $7.54^{\mathrm{ij}}$ & $6.91^{\mathrm{efg}}$ & $6.47^{b c}$ & $7.37^{\mathrm{hi}}$ & $6.83^{\text {def }}$ & $6.30^{\mathrm{ab}}$ \\
\hline & MP (Vac) & & $7.40^{\text {hi }}$ & $6.73^{\text {cde }}$ & $6.29^{\mathrm{ab}}$ & $7.21^{\mathrm{gh}}$ & $6.59^{\mathrm{bcd}}$ & $6.13^{\mathrm{a}}$ \\
\hline \multirow{3}{*}{ OAA } & $\mathrm{PP}$ & & $7.72^{\mathrm{f}}$ & $7.55^{\mathrm{ef}}$ & $7.22^{\mathrm{cd}}$ & $7.59^{\mathrm{ef}}$ & $7.30^{\text {cde }}$ & $7.12^{\mathrm{c}}$ \\
\hline & MP & $8.17^{g}$ & $7.65^{\mathrm{f}}$ & $7.28^{\mathrm{cd}}$ & $6.83^{b c}$ & $7.45^{\mathrm{def}}$ & $7.19^{\mathrm{cd}}$ & $6.60^{\mathrm{ab}}$ \\
\hline & MP (Vac) & & $7.70^{\mathrm{f}}$ & $7.20^{\mathrm{cd}}$ & $6.75^{\mathrm{b}}$ & $7.53^{\mathrm{ef}}$ & $7.07^{\mathrm{c}}$ & $6.41^{\mathrm{ab}}$ \\
\hline
\end{tabular}

Values with different superscripts differ significantly $(\mathrm{p}<0.05)$; Values are mean $\pm S D,(n=20)$. 
time up to 9 months irrespective of conditions of storage. Initially bar scored a texture value of 8.09 , decreased significantly $(\mathrm{P}<0.05)$ to $7.10 \& 6.80$ packed in PP films, $6.47 \& 6.30$ packed in MP films and 6.29 and 6.13 in samples packed under vacuum in MP films at ambient and $37^{\circ} \mathrm{C}$ temperature conditions respectively. The bars packed in PP films scored slightly better value for texture, may be due to the slight sogginess of a bar with slightly more moisture which facilitated easy bite from the panellists as compared to the bars stored in MP films (with and without vacuum). Figiel and Czopek (2006) [23] has also reported a significant decrease in hardness of a candy, when there was an increase in moisture content by 0.5 units. Vacuum packing of bars also aided in enhancing the hardness, as vacuum packing of dry cured ham in multilayered laminated film has resulted in increased hardness, cohesiveness etc when samples were stored for 8 weeks as compared to the non vacuum stored samples [24]. The development of tough or hard texture in protein rich bar may be attributed to the thiol-disulfide interchange reactions during storage, which leads to cross linking, aggregation and network formation [25] [26]. Surface hydrophobicity and more ordered secondary structure of protein can also cause hardening during storage [27]. Initially bar received an OAA score of 8.17 on a 9 point hedonic scale which decreased significantly $(p<0.05)$ to a lower value of 6.41 in samples packed in MP films under vacuum at $37^{\circ} \mathrm{C}$ followed by MP alone which scored 6.60 under same temperature conditions. The next lowest value was observed for the samples stored under ambient $\left(15^{\circ} \mathrm{C}-34^{\circ} \mathrm{C}\right)$ conditions, which scored an OAA score of 6.83 and 6.75 when packed in MP films with out and with vacuum respectively. Since lower limit for the acceptability of the product was considered as 7 on a 9 Point Hedonic scale, the bars packed in PP films was found acceptable for 9 months, while the samples packed in MP films (with and without vacuum) remained stable for 6 months only under both the temperature conditions.

The effect of water activity $\left(\mathrm{a}_{\mathrm{w}}\right)$ on lipid peroxidation of choco quinoa nutri bar at $\mathrm{a}_{\mathrm{w}}$ levels of $0.0,0.33,0.57$ and 0.73 during 40 days of storage at ambient conditions $\left(15^{\circ} \mathrm{C}-34^{\circ} \mathrm{C}\right)$ are represented in Figure 3. The initial moisture content of the bar was $6.87 \%$, changed significantly $(\mathrm{p}<0.05)$ to $0.38,4.73,7.80$, 11.27 at $0.0,0.33,0.57$ and $0.73 \mathrm{a}_{\mathrm{w}}$ levels at the end of 40 days of storage. Significant $(\mathrm{p}<0.05)$ decrease in moisture content was observed at 0.00 and $0.33 \mathrm{a}_{\mathrm{w}}$, while samples kept at 0.57 and $0.73 \mathrm{a}_{\mathrm{w}}$ levels showed a significant $(\mathrm{p}<0.05)$ increase in their moisture content during storage. Samples stored at all $\mathrm{a}_{\mathrm{w}}$ levels attained equilibrium in their moisture contents after 30 days of storage and remained almost constant thereafter till the end of the study.

Lipid oxidation as evaluated by measuring changes in PV and FFA values showed a significant $(\mathrm{p}<0.05)$ increase at all $\mathrm{a}_{\mathrm{w}}$ levels, showing higher degree of increase at $0.0 \mathrm{a}_{\mathrm{w}}$ followed by 0.57 and $0.73 \mathrm{a}_{\mathrm{w}}$ and comparatively less at $0.33 \mathrm{a}_{\mathrm{w}}$. $\mathrm{PV}$ and FFA values increased from $3.66 \mathrm{meq} \mathrm{O}_{2} / \mathrm{kg}$ fat and $1.87 \%$ oleic acid at 0 day to 25.56 meq $\mathrm{O}_{2} / \mathrm{kg}$ fat \& $4.22 \%$ oleic acid, $22.93 \mathrm{meq} \mathrm{O}_{2} / \mathrm{kg}$ fat \& $4.32 \%$ oleic acid and $23.26 \mathrm{meqO}_{2} / \mathrm{kg}$ fat \& $4.46 \%$ oleic acid at $0.00,0.57$ and $0.73 \mathrm{a}_{\mathrm{w}}$ levels, 
(a) Changes in moisture (\%)

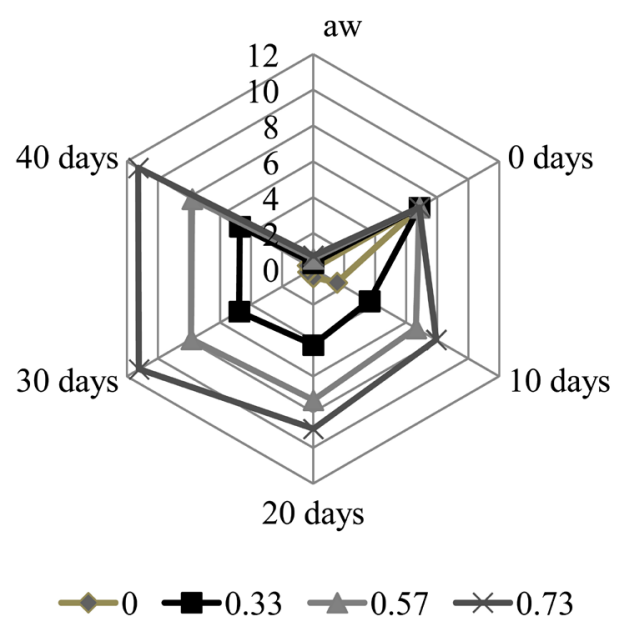

(c) Changes in peroxide value (meq $\mathrm{O}_{2} / \mathrm{kg}$ fat)

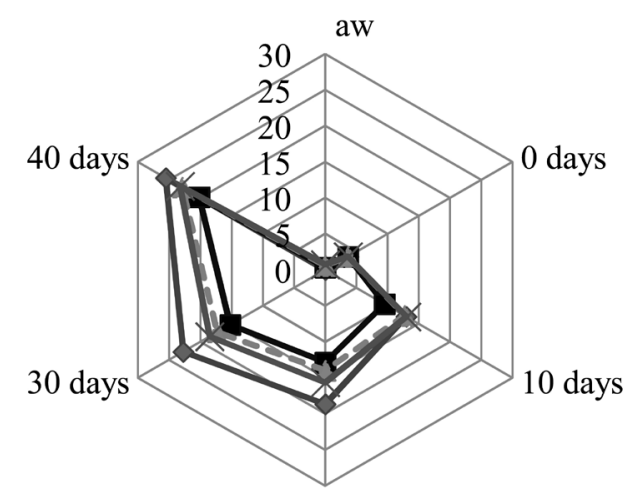

20 days (b) Changes in free fatty acids (\% Oleic acid)

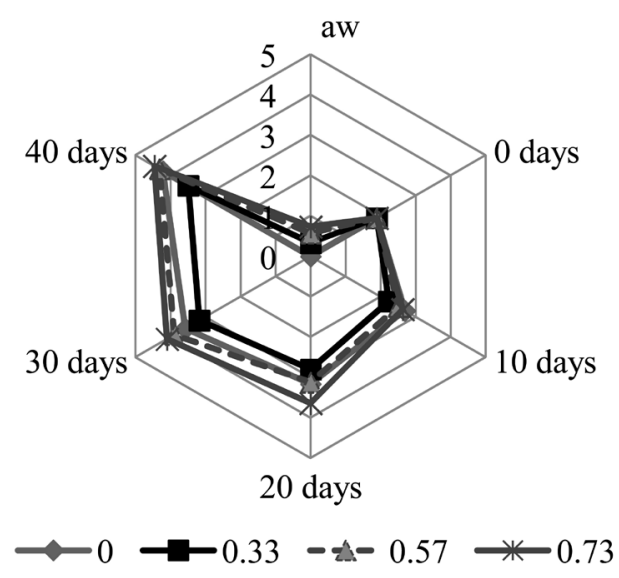

(d) Changes in antioxidant activity $(\%$ Inhibition)
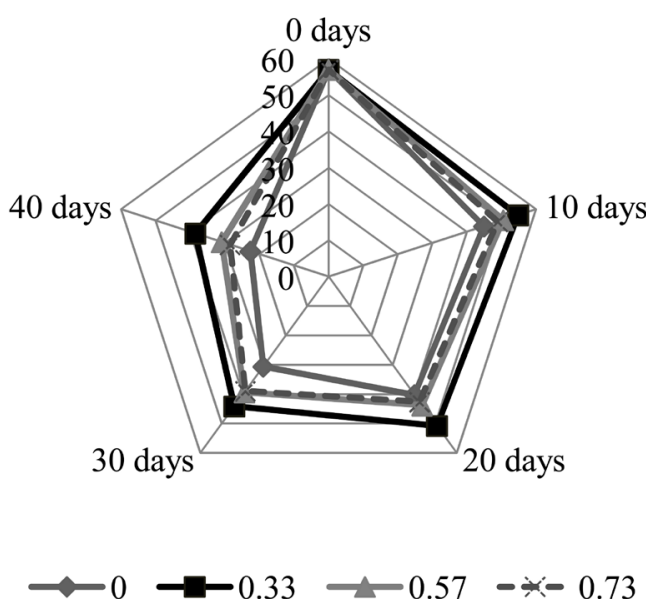

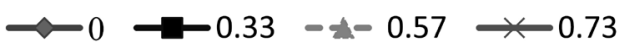

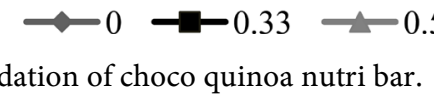

Figure 3. Effect of water activity $\left(\mathrm{a}_{\mathrm{w}}\right)$ on the lipid peroxidation of choco quinoa nutri bar.

respectively, at the end of 40 days of storage at ambient conditions. At $0.33 \mathrm{a}_{\mathrm{w}}$, both PV and FFA showed slower increase from 3.66 to 20.21 meq $\mathrm{O}_{2} / \mathrm{kg}$ fat and $1.87 \%$ to $3.50 \%$ oleic acid, thus indicating the maximum stability of the product at $0.33 \mathrm{a}_{\mathrm{w}}$. The stability of the bars at $0.33 \mathrm{a}_{\mathrm{w}}$ may be attributed to the formation of hydrogen bonds between water and peroxides which prevent the decomposition of hydroperoxides. Also, water hydrates transition metal ions thereby reducing their activity to decompose hydroperoxides [28]. The results obtained from our study are in conformity with published data [28] [29]. The increase in FFA may be due to the hydrolysis of fats in the presence of water, and followed the same trend as that of PV at different $a_{w}$ levels.

Antioxidants are the compounds which inhibit the process of lipid oxidation by reacting with the radical formed from fat to form a stable radical, which do not quickly react with reactive oxygen, thereby extend the shelf life of processed foods by protecting them against deterioration [30]. It is evident from the 


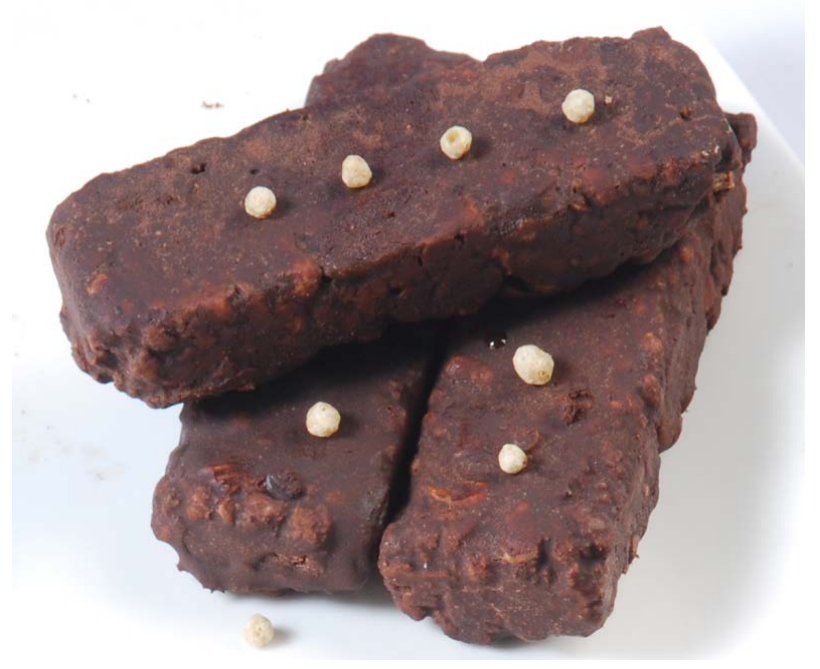

Figure 4. Photograph of choco quinoa nutri bar.

present study that, the bar which initially showed $57 \%$ inhibition of peroxidation, showed a significant $(\mathrm{p}<0.05)$ decrease in the antioxidant activity at all $\mathrm{a}_{\mathrm{w}}$ levels during 40 days of storage as the lipid oxidation progressed. Lipid oxidation and antioxidant degradation found maximum at $0.00 \mathrm{a}_{\mathrm{w}}$ and minimum at 0.33 $\mathrm{a}_{\mathrm{w}}$. Antioxidant activity decreased significantly ( $\mathrm{p}<0.05$ ) from $57.01 \%$ to $22.62 \%, 38.55 \%, 30.94 \%$ and $28.48 \%$ inhibition at $0.0,0.33,0.57$ and $0.73 \mathrm{a}_{\mathrm{w}}$ levels respectively, at the end of the storage period. The decrease in antioxidant activity was found to have a good correlation with the increase in lipid oxidation at the all the $\mathrm{a}_{\mathrm{w}}$ levels during storage.

Microbiological analysis carried out in choco quinoa nutri bar (Figure 4) at regular intervals of time, revealed no microbial counts. The samples were found free from yeast and mold counts and SPC count was found within the acceptable limit during the entire storage period.

\section{Correlation Analysis}

The chemical changes like PV, FFA, TBA and browning observed during storage was found to be negatively correlated $(r \geq-0.99)$ with over all acceptability (OAA) scores. The correlation between PV \& OAA, FFA \& OAA, TBA \& OAA and Browning \& OAA were found to be $-0.97,-0.99,-0.99,-0.97 \&-0.99$, $-0.99,-0.99,-0.97 \&-0.99,-0.98,-0.97,-0.95$ for the bars packed in PP, MP and MP (Vacuum) respectively during storage at ambient conditions $\left(15^{\circ} \mathrm{C}\right.$ $34^{\circ} \mathrm{C}$ ). It was observed from the study that, correlation between the chemical changes and OAA for the samples stored under $37^{\circ} \mathrm{C}$ was not varied much with that of ambient conditions, because the chemical changes that took place at both the temperature conditions, though observed significant, but not affected the sensory quality in terms of OAA which was clearly revealed by sensory panellists. As far as the texture of the bar is concerned, the texture was found to be positively correlated $(r>0.97)$ with OAA at both the temperature conditions. 


\section{Conclusion}

A highly nutritious bar can be prepared with the incorporation of quinoa to enhance its protein quality. Bars stored at $37^{\circ} \mathrm{C}$ underwent deterioration at a slightly faster rate as compared to the bars stored at ambient conditions. Packing in vacuum films was not found beneficial in extending the shelf life of the bar. Even though bar remained chemically, sensorily and microbiologically safe during the entire storage period, increase in the hardness was found to be the limiting factor for the acceptability of the bar thus restricting the shelf life to 6 months in the samples packed in MP films (with/without vacuum) and 9 months in PP films under both the temperature conditions.

\section{References}

[1] Velencia, R.A.M.R.C. and Serna, L.A. (2011) Quinoa (Chenopodium quinoa Willd) as a Source of Dietary Fiber and Other Functional Components. Ciencia e Tecnologia Alimentos, 31, 225-230. https://doi.org/10.1590/S0101-20612011000100035

[2] Koziol, M.J. (1992) Chemical Composition and Nutritional Value of Quinoa (Chenopodium quinoa Willd.). Journal of Food Composition Analysis, 5, 35-68. https://doi.org/10.1016/0889-1575(92)90006-6

[3] Ranhotra, G.S., Gelroth, J.A., Glaser, B.K., Lorenz, K.J. and Johnson, D.L. (1993) Composition and Protein Nutritional Quality of Quinoa. Cereal Chemistry, 70, 303-305.

[4] Bhargava, A., Rana, T., Shukla, S. and Ohri, D. (2005) Seed Protein Electrophoresis of Some Cultivated and Wild Species of Chenopodium. Plant Biology, 49, 505-511. https://doi.org/10.1007/s10535-005-0042-5

[5] Vega-Galvez, A., Miranda, M., Vergara, J., Uribe, E., Puente, L. and Martinez, E.A. (2010) Nutrition Facts and Functional Properties of Quinoa (Chenopodium quinoa Willd) an Ancient Andean Grain: A Review. Journal of the Science of Food and Agriculture, 9, 2541-2547. https://doi.org/10.1002/jsfa.4158

[6] Repo-Carrasco, R., Espinoza, C. and Jacobsen, S.E. (2003) Nutritional Value and Use of the Andean Crops Quinoa (Chenopodium quinoa) and Kaniwa (Chenopodium pallidicaule). Food Review International, 19, 179-189. https://doi.org/10.1081/FRI-120018884

[7] Yadav, L. and Bhatnagar, U. (2015) Optimization of Ingredients in Cereal Bar. Food Science Research Journal, 6, 273-278. https://doi.org/10.15740/HAS/FSRJ/6.2/273-278

[8] AOAC (1984) Official Methods of Analysis. 14th Edition, Association of Official Analytical Chemists, Arlington, Virginia.

[9] AOCS (1990) Official Methods and Recommended Practice of American Oil Chemical Society. 4th Edition, AOCS, Champaign, Illinois.

[10] Khan, M.A., Semwal, A.D., Sharma, G.K., Yadav D.N. and Srihari, K.A. (2008) Studies on the Development and Shelf Stability of Groundnut (Arachis hypogea) Burfi. Journal of Food Quality, 31, 612-626. https://doi.org/10.1111/j.1745-4557.2008.00224.x

[11] Henderson, J.W., Robert, D.R., Brian, A.B. and Cliff, W. (2000) Rapid, Accurate, Sensitive and Reproducible HPLC Analysis of Amino Acids. Agilent Technologies, Application Note, Publication No: 5980-1193.

[12] Tarledgis, B.G., Watts, B.M., Younathan, M.J. and Dugan Jr., L. (1960) A Distilla- 
tion Method for the Qualitative Determination of Malonal-Dehyde in Rancid Food. Journal of American Oil Chemist Society, 37, 44-47. https://doi.org/10.1007/BF02630824

[13] Braca, A., Tommasi, N.D., Bari. L.D., Cosimo, Pizza, C., Mateo, Politi, M. and Morelli, I. (2001) Antioxidant Principles from Bauhinia terapotensis. Journal of Natural Products, 64, 892-895. https://doi.org/10.1021/np0100845

[14] APHA (1992) Compendium Methods for the Microbiological Examination of Foods. 16th Edition, American Public Health Association, Washington DC.

[15] Khan, M.A., Mahesh, C., Semwal, A.D., Sharma, G.K., Srihari S.P., Jayaprahash, C and Srihari, K.A (2014) Studies on the Shelf Life Enhancement of Potato Stuffed Parotha Using Thermal Processing. Journal of Food Science and Technology, 51, 2190-2196. https://doi.org/10.1007/s13197-014-1269-y

[16] Larmond, E. (1977) Laboratory Methods for the Sensory Evaluation of Foods. Canada Dept. of Agriculture publication, Ottawa.

[17] Snedecar, G.N. and Cochran, W.G. (1968) Statistical Methods. 6th Edition, Oxford and IBH Publishing Company, New Delhi.

[18] National Academy of Sciences (1975) Underexploited Tropical Plants with Promising Economic Value. RESS, Washington DC, 145.

[19] Prakash, D. and Pal, M. (1998) Chenopodium: Seed Protein, Fractionation and Amino Acid Composition. International Journal of Food Sciences and Nutrition, 49, 271-275. https://doi.org/10.3109/09637489809089398

[20] Bhargava, A., Shukla, S. and Ohri, D. (2003) Genetic Variability and Heritability of Selected Traits during Different Cuttings of Vegetable Chenopodium. Industrial Journal Genetic Plant Breeding, 63, 359-360.

[21] Wasowicz, E., Gramza, A., Hes, M., Jelen, H.H., Korczak, J., Malecka, M., Mildner-Szkudlarz, S., Rudzinska, M., Samotyja, U. and Zawirska-Wojtasiak, R. (2004) Oxidation of Lipids in Food. Polish Journal of Food and Nutrition Sciences, 13, 87-100.

[22] Bourne, M.C. (2002) Food Texture and Viscosity: Concept and Measurement. 2nd Edition, Academic Press, San Diego, 15. https://doi.org/10.1016/B978-012119062-0/50001-2

[23] Figiel, A. and Czopek, A.T. (2006) The Effect of Candy Moisture Content on Texture. Journal of Food Service, 17, 189-195. https://doi.org/10.1111/j.1745-4506.2006.00037.x

[24] Esteban, M.G., Ansorena, D. and Astiasaran, I. (2004) Comparison of Modified Atmospheric Packaging and Vacuum Packaging for Long Period Storage of Dry Cured Ham, Its Effects on Colour, Texture and Microbial Quality. Meat Science, 67, 57-63. https://doi.org/10.1016/j.meatsci.2003.09.005

[25] Zhou, P., Liu, X. and Labuza, T.P. (2008) Effects of Moisture-Induced Whey Protein Aggregation on Protein Conformation, the State of Water Molecules, and the Microstructure and Texture of High-Protein-Containing Matrix. Journal of Agricultural and Food Chemistry, 56, 4534-4540. https://doi.org/10.1021/jf073216u

[26] Simon, M.L., Jason, P.M., Lawrence, K. and Harjinder, S. (2009) Physico-Chemical Changes in Model Protein Bar during Storage. Food Research International, 42, 798-806. https://doi.org/10.1016/j.foodres.2009.03.002

[27] Baier, S.K., Guthrie, B.D., Elmore, D.L., Smith, S.A., Lendon, C.A., Muroski, A.R. and Aimutis, W. (2007) Influence of Extrusion on Protein Conformation and Shelf-Life Extension of Nutritional Bars. The International Symposium on the 
Properties of Water X, Bangkok, 2-7 September 2007.

[28] Labuza, T.P. (1978) Oxidative Changes in Food at Low and Intermediate Moisture Foods. In: Duckworth, R.B., Ed., Water Relation of Foods, Academic, London, 455-474.

[29] Semwal, A.D., Sharma, G.K., Patki, P.E., Padmashre, A. and Arya, S.S. (2001) Studies on the Development and Storage Stability of Instant Vegetable Pulav Mix. Journal of Food Science and Technology, 38, 231-234.

[30] Kumar, Y., Yadav, D.N., Ahmed, T. and Narsaiah, K. (2015) Recent Trends in the Use of Natural Antioxidants for Meat and Meat Products. Comprehensive Reviews in Food Science and Food Safety, 14, 796-812.

https://doi.org/10.1111/1541-4337.12156 